\title{
Matrilin-3 Role in Cartilage Development and Osteoarthritis
}

\author{
Manjunatha S. Muttigi ${ }^{1,2}$, Inbo Han ${ }^{3}$, Hun-Kuk Park ${ }^{4}$, Hansoo Park ${ }^{1, *}$ and Soo-Hong Lee ${ }^{2, *}$ \\ 1 School of Integrative Engineering, Chung-Ang University, Seoul 06911, Korea; \\ manjunatha.muttigi@gmail.com \\ 2 Department of Biomedical Science, CHA University, Seongnam-Si 13488, Korea \\ 3 Department of Neurosurgery, CHA Bundang Medical Center, CHA University, Seongnam-si 13496, Korea; \\ hanib@cha.ac.kr \\ 4 Department of Biomedical Engineering, Collage of Medicine, Kyung Hee University, Seoul 02447, Korea; \\ sigmoidus@khu.ac.kr \\ * Correspondence: heyshoo@cau.ac.kr (H.P.); soohong@cha.ac.kr (S.-H.L.); \\ Tel.:+82-2-820-5804 (H.P.); +82-031-881-7143 (S.-H.L.); Fax: +82-2-813-8159 (H.P.); +82-31-881-7249 (S.-H.L.)
}

Academic Editor: Ge Zhang

Received: 19 February 2016; Accepted: 13 April 2016; Published: 20 April 2016

\begin{abstract}
The extracellular matrix (ECM) of cartilage performs essential functions in differentiation and chondroprogenitor cell maintenance during development and regeneration. Here, we discuss the vital role of matrilin-3, an ECM protein involved in cartilage development and potential osteoarthritis pathomechanisms. As an adaptor protein, matrilin-3 binds to collagen IX to form a filamentous network around cells. Matrilin-3 is an essential component during cartilage development and ossification. In addition, it interacts directly or indirectly with transforming growth factor $\beta$ (TGF- $\beta$ ), and bone morphogenetic protein 2 (BMP2) eventually regulates chondrocyte proliferation and hypertrophic differentiation. Interestingly, matrilin-3 increases interleukin receptor antagonists (IL-Ra) in chondrocytes, suggesting its role in the suppression of IL-1 $\beta$-mediated inflammatory action. Matrilin-3 downregulates the expression of matrix-degrading enzymes, such as a disintegrin metalloproteinase with thrombospondin motifs 4 (ADAMTS4) and ADAMTS5, matrix metalloproteinase 13 (MMP13), and collagen $\mathrm{X}$, a hypertrophy marker during development and inflammatory conditions. Matrilin-3 essentially enhances collagen II and aggrecan expression, which are required to maintain the tensile strength and elasticity of cartilage, respectively. Interestingly, despite these attributes, matrilin-3 induces osteoarthritis-associated markers in chondrocytes in a concentration-dependent manner. Existing data provide insights into the critical role of matrilin-3 in inflammation, matrix degradation, and matrix formation in cartilage development and osteoarthritis.
\end{abstract}

Keywords: matrilin-3; extracellular matrix; cartilage; hypertrophy; interleukin receptor antagonist; osteoarthritis

\section{Introduction}

\subsection{Articular Cartilage and Osteoarthritis}

Articular cartilage is a highly specialized tissue covering the end of bones [1]. It mainly consists of hyaline cartilage, with a high collagen II content and a rich proteoglycan matrix [2]. It reduces joint friction by functioning as a shock absorber; thereby protecting the bone ends from mechanical damage [3,4]. Articular cartilage tissue consists of four zones: superficial, intermediate, deep, and calcified cartilage, and has no blood, lymph, or nerve supply [2,3,5]. Cartilage defects can occur owing to osteoarthritis, autoimmune conditions like rheumatoid arthritis, osteochondritis dissecans, and osteonecrosis [6]. However, owing to a lack of blood supply, cartilage repair fails to occur. Furthermore, 
a dense extracellular matrix (ECM) of cartilage also prevents self-repair by inhibiting the migration of chondrocytes to the injured site $[7,8]$. Therefore, in this review, we discuss the initiation and progression of osteoarthritis, and the role of matrilin-3 in maintaining cartilage structure, function, and disease development.

Osteoarthritis is a slowly progressive and degenerative disorder characterized by cartilage functional impairment, subchondral bone changes, and osteophyte formation in the absence of autoimmune or anti-inflammatory mechanisms $[3,9]$. It impairs mobility and lowers extremity function in peripheral joints [9-11]. Osteoarthritis is primarily a mechanically induced disease with an etiology to which both acquired and genetic factors contribute [12]. Polymorphisms and mutations in several genes, such as transforming growth factor $\beta(T G F-\beta)$, bone morphogenetic protein $(B M P)$, growth differentiation factor 5 (GDF5), secreted frizzled-related protein 3 (FRZB), and matrilin-3 (MATN3) predisposes individuals to early-onset osteoarthritis [13-20].

In the knee joint, the epiphysis is covered with an epiphyseal plate, also called the growth plate. The epiphyseal plate is composed of resting, proliferative, and hypertrophic zones, which contain reserve/resting, proliferative, and hypertrophic chondrocytes, respectively [21]. During development, long bones elongate via the endochondral ossification process. This process involves chondrocyte terminal differentiation, during which apoptosis occurs. Subsequently, these terminally differentiated cells undergo apoptosis and are replaced by osteoblasts and osteoclasts [22]. Both cartilage and subchondral bone structure and remodeling are regulated by several factors. However, a change in the balance of articular cartilage and subchondral bone remodeling is associated with the initiation and progression of osteoarthritis [23-26].

\subsection{Changes in the Remodeling Balance of Cartilage}

During normal conditions, articular chondrocytes and subchondral osteoblasts receive mechanical loads and strain on a daily basis and homeostatic mechanisms react accordingly [27]. Eventually, due to predisposing osteoarthritis factors, homeostasis cannot sufficiently compensate for the mechanical load and strain on the body [27]. During this initial period, there is increased proliferation and enhanced remodeling at the cellular level in both cartilage and bone [28]. This is evidently an effort to maintain structural integrity as well as homeostasis in the bone and cartilage. However, an imbalance between chondrocyte anabolism and catabolism leads to the secretion of pro-inflammatory cytokines, including interleukin-1 $\beta$ (IL-1 $\beta$ ), matrix metalloproteinases (MMPs), and a disintegrin and metalloproteinase with thrombospondin motifs (ADAMTS) [29,30]. Inflammation in the microenvironment created by IL-1 leads to the loss of ECM components and structure associated with chondrocyte hypertrophy and terminal differentiation. During this process of disease development, chondrocytes express vascular endothelial growth factor (VEGF), Runt-related transcription factor (RUNX2), collagen X, and MMP13 [10,30]. This shift towards hypertrophy is accompanied by the calcification of the ECM around hypertrophic chondrocytes. Hypertrophic changes and increased cellular activity lead to subchondral bone sclerosis, along with a thickening of the cortical plate and remodeling of trabeculae [31].

Several mechanisms are strongly involved in cellular signaling to stimulate vascular invasion by angiogenic factors, such as VEGF. Subsequently, the formation of vascular communication channels in subchondral bone pores facilitates molecular transport between bone and cartilage [32-34]. Nevertheless, the chronological order of structural changes in cartilage and subchondral bone during the initiation and progression of osteoarthritis remains unclear [35,36]. It is evident that changes in both cartilage and bone occur before the onset of clinical symptoms. Although cartilage and bone are affected during the initiation and progression of osteoarthritis, their close physical relationship plays a critical role in its repair via biochemical and molecular cross-talk [2,27]. Therefore, a number of studies have focused on the role of growth factors and cytokines in cartilage and bone as targets for the development of new treatments. One potential target is matrilin-3; its role in articular cartilage is discussed below. 


\section{Role of Matrilin-3}

\subsection{Matrilin-3: Bone-Cartilage ECM Modulator}

Matrilin-3 is a non-collagenous ECM protein that functions as an adaptor protein [37,38]. The matrilins form a four-member family, including matrilin-1, matrilin-2, matrilin-3, and matrilin-4. Each member of the family presents one or two Von Willebrand factor A (VWFA) domains, a variable number of epidermal growth factor (EGF)-like domains, and an $\alpha$-helical coiled-coil domain (Figure 1). Among these, matrilin-3 is the shortest member of the family, containing one von VWFA, four EGF-like domains, and a C-terminal coiled-coil domain [37-40].

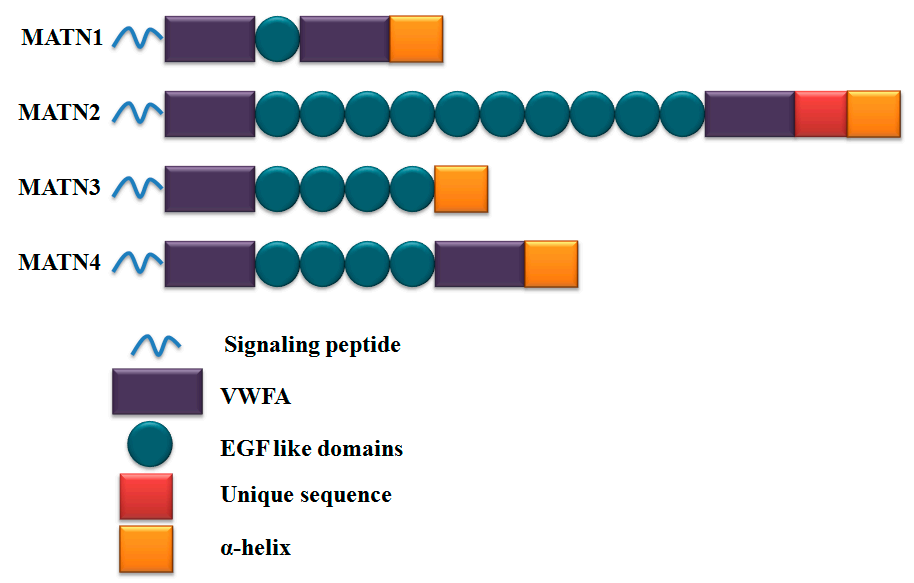

Figure 1. Domain structure of each member of the matrilin family. Each member of the family consists of VWFA, EGF-like domains, and an $\alpha$-helical oligomerization domain. Abbreviation: MATN, matrilin; VWFA, von Willebrand factor A; EGF, epidermal growth factor.

The matrilin-3 gene is expressed in chondroblasts and osteoblasts, but not in hypertrophic chondrocytes [41,42]. Matrilin-3 protein distribution is observed in cartilaginous tissues, such as articular and epiphyseal cartilage, the sternum, and in the cartilaginous anlage of developing bones [41]. It is also present inside both the interterritorial matrix and lacunae of the resting, proliferating, hypertrophic, and calcified cartilage zones and in the perichondrium [41]. As an ECM protein, matrilin-3 plays a critical role in the formation of a filamentous network: collagen (collagen IX)-dependent network connecting cells and the collagen-independent pericellular network [38,43]. Additionally, it is an important component in skeletal development, e.g., it is involved in mesenchymal differentiation, chondrocyte terminal differentiation, de-differentiation, and bone mineral density maintenance [42,44-49].

\subsection{Role of Matrilin-3 in Chondrogenesis, Terminal Differentiation of Chondrocytes, and Ossification}

The growth plate or epiphyseal plate contains three types of chondrocytes: reserve/resting, proliferative, and hypertrophic. These three types of chondrocytes are formed under a tightly regulated process of proliferation and terminal differentiation. The hypertrophic chondrocytes undergo apoptosis, degradation, and are then replaced by bone (ossification). Any change in the regulation of this process leads to osteochondral dysplasia or skeletal disorders [21].

Missense mutations in the VWFA domain of matrilin-3 have been observed in patients with multiple epiphyseal dysplasia (MED) [45,50]. MED is characterized by delayed and irregular ossification of the epiphysis. Point mutations in mouse matrilin-3, such as R116W and C299S, increase GADD153 levels, affecting protein folding and trafficking since matrilin-3 is retained and accumulates in the endoplasmic reticulum [51,52]. This results in the reduced formation of the filamentous network around cells. These two mutations (R116W and C299S) are similar to human matrilin-3 point mutations 
linked to chondrodysplasia [51]. Furthermore, Cotteril et al. observed that mutated matrilin-3 is retained in the dilated cisternae of the endoplasmic reticulum [53]. Recently, Jayasurya et al. showed that matrilin-3 is essential for TGF- $\beta$ signaling [54]. In spondyloepimetaphyseal dysplasia (SEMD) and multiple epiphyseal dysplasia (MED), mutations in the matrilin-3 gene cause an aberrant response towards TGF- $\beta$ and differentiation of ATDC 5 chondroprogenitor cells. Furthermore, wild-type matrilin-3 overexpression in ATDC5 chondroprogenitor cells leads to spontaneous chondrogenic differentiation, which is confirmed by increases in collagen II and aggrecan gene expression and in the glycosaminoglycan (GAG) content. Moreover, MED and SEMD mutations cause increased collagen $X$ expression, resulting in premature hypertrophy [54]. In addition, the roles of matrilin-3 in chondrogenesis, premature chondrocyte maturation, and ossification have been confirmed using functional matrilin-3 knockout mice. In matrilin-3 null mice, chondrocytes present in cartilage prematurely transform into a prehypertrophic and hypertrophic phenotype, and form an expanded zone of hypertrophy [48]. BMP2 is a well-known factor responsible for the hypertrophic differentiation of chondrocytes [55]. Yang et al. [56] showed that matrilin-3 binds to BMP2 based on a solid-phase binding assay and surface plasmon resonance assay. Binding between matrilin-3 and BMP2 was also confirmed using an immunoprecipitation assay. Yang et al. [56] also suggested that matrilin-3 binds to BMP2 and limits its availability to bind the BMP receptor. It was proposed that multiple EGF domains of matrilin-3 cluster together with the coiled-coil domain to form a pocket and bind to BMP-2, thereby inhibiting BMP-2 activity. The binding of matrilin-3 with BMP2 prevents BMP receptor-mediated Smad1 phosphorylation and downstream collagen $X$ expression in chondrocytes [56]. Therefore, matrilin-3 acts as an antagonist to prevent the hypertrophic terminal differentiation of chondrocytes.

\subsection{Role of Matrilin-3 in Osteoarthritis}

Mutations in matrilin-3 are associated with disorders in skeletal development and predisposes individuals to develop osteoarthritis $[19,20,45,50,57]$. Interestingly, the expression of matrilin-3 is increased in osteoarthritis and its expression levels are correlated with disease severity [58]. Both matrilin-3 mRNA and protein expression were detected in the middle and deep cartilage zone and in subchondral bone. Furthermore, increased matrilin-3 mRNA expression was also found in proliferating chondrocytes near the articular joint surface, without prominent protein expression in the ECM [58]. This increased expression may be a cellular response to the osteoarthritic environment. Previously, Jayasurya et al. [47] showed that a soluble recombinant matrilin-3 at concentrations of 100 and $200 \mathrm{ng} / \mathrm{mL}$ induces an interleukin 1 receptor antagonist (IL-1Ra), even in the presence of interleukin-1 $\beta$ (IL-1 $\beta$ ) in chondrocytes. Matrilin-3 increases collagen II and aggrecan, and reduces ADAMTS5, which is mediated by IL-Ra. Matrilin-3 also suppresses MMP-13 in chondrocytes-suggesting a role in the suppression of hypertrophy caused by inflammation [47]. However, the mechanism by which matrilin-3 regulates IL-Ra is currently unknown. It is possible that matrilin-3 mediates signals via integrins or other plasma membrane receptors such, as EGF receptors (since matrilin-3 have EGF like domains), in chondrocytes [59]. However, the matrilin-3 functions mediated by these receptors have yet to be determined. In contrast to the above findings, Klatt et al. [60] showed that 5 to $50 \mu \mathrm{g} / \mathrm{mL}$ matrilin-3 increases the expression of MMP1, MMP3, MMP13, IL-1 $\beta$, IL-6, IL-8, iNOS and COX-2 in chondrocytes. Increased expression of MMPs and pro-inflammatory markers could increase ECM catabolism and inflammation. Furthermore, the overexpression of ADAMTS4 and ADAMTS5 increases ECM degradation and elevates the levels of the free form of matrilin-3. It is hypothesized that elevated levels of matrilin-3 could in turn increase the expression of ADAMTS4 and ADAMTS5 via IL-1 $\beta$ [60]. In support of this, Klatt et al. [61] showed that VWFA domains present in matrilin-3 are responsible for IL-6 expression in primary human chondrocytes (See Figure 2). Matrilin-3 function shifts from an anabolic to a catabolic effect on ECM components, possibly due to a change from a very low concentration range (100 to $200 \mathrm{ng} / \mathrm{mL}$ ) to a supra-physiological range ( 5 to $50 \mu \mathrm{g} / \mathrm{mL}$ ). A concentration of 5 to $50 \mu \mathrm{g} / \mathrm{mL}$, which is higher than 
physiological levels, increases degenerative protease levels and inflammation in chondrocytes, possibly via negative feedback mechanism [47].

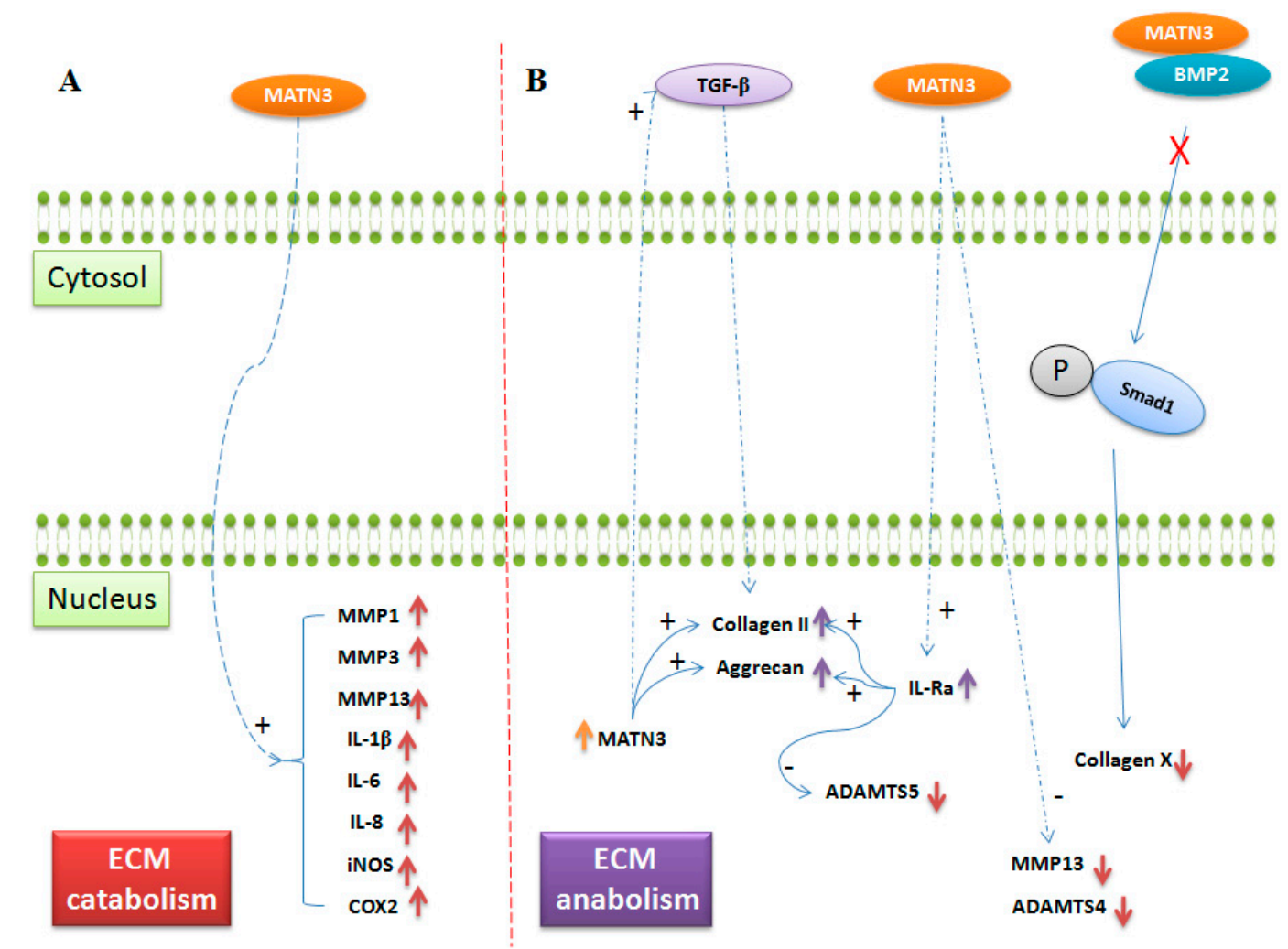

Figure 2. The schematic diagram illustrates the role of matrilin-3 in ECM modulation of cartilage. (A) ECM catabolism: Matrilin-3 at supra-physiological concentrations ( $\sim 5$ to $50 \mu \mathrm{g} / \mathrm{mL}$ ) increases MMP1, MMP3, MMP13, IL-1 $\beta$, IL-6, IL-8, iNOS, and COX2 expression in chondrocytes (red upward arrows); (B) ECM anabolism and hypertrophy: Matrilin-3 mediates the TGF- $\beta$ signaling pathway. The overexpression of matrilin-3 (orange upward arrow) increases collagen II and aggrecan expression. Matrilin-3 at low concentrations ( 100 to $200 \mathrm{ng} / \mathrm{mL}$ ) increases IL-Ra expression, which increases collagen II and aggrecan expression (purple upward arrows), and reduces ADAMTS5. Recombinant matrilin-3 reduces ADAMTS4 and MMP13 expression (red downward arrows). Matrilin-3 binds to BMP2, thereby inhibiting BMP downstream signaling, collagen $X$ expression, and chondrocyte hypertrophic differentiation (red cross in B). Abbreviations: ECM, extracellular matrix; MMP, matrix metalloproteinase; IL, interleukin; iNOS, induced nitric oxide synthase; COX2, cyclooxygenase; TGF- $\beta$, transforming growth factor $\beta$; IL-Ra, Interleukin receptor antagonist; ADAMTS, a disintegrin and metalloproteinase with thrombospondin motifs; BMP, bone morphogenetic protein. Dashed arrows (blue), unidentified signaling pathways; solid arrow (blue), identified signaling pathway; (+), positive regulatory effect; $(-)$, negative regulatory effect.

Vincourt et al. [62] estimated thatmatrilin-3 in the synovial fluid of osteoarthritic patients ranges from $80 \mathrm{ng} / \mathrm{mL}$ to $5.7 \mu \mathrm{g} / \mathrm{mL}$. Furthermore, they compared the effects of the soluble free form of matrilin-3 and the artificially immobilized matrilin-3 on chondrocytes. The treatment of chondrocytes with soluble matrilin-3 increased ECM catabolism, while treatment with the immobilized protein increased ECM anabolism. Soluble matrilin-3 treatment at concentrations of $<10 \mu \mathrm{g} / \mathrm{mL}$ induces collagen II expression. On the other hand, matrilin-3 at concentrations of $\geqslant 20 \mu \mathrm{g} / \mathrm{mL}$ increases MMP13 expression at both the mRNA and protein levels. In contrast, artificially immobilized matrilin- 3 on a plastic surface binds to chondrocytes via a $\alpha 5 \beta 1$ integrin-dependent mechanism. Additionally, TGF- $\beta$ stimulation of chondrocytes allows the integration of matrilin- 3 into the chondrocyte ECM. The binding of integrated matrilin-3 increases AKT phosphorylation and in turn, increases chondrocyte 
survival and ECM synthesis [62]. The above studies suggest that the initial increase in matrilin-3 possibly initiates a defense mechanism that increases IL-Ra, collagen II, and aggrecan in order to limit inflammation and maintain the tensile and elastic strength of cartilage tissues [47]. However, a continual increase in soluble protein to a supra-physiological level is lethal to chondrocytes [60]. However, even when immobilized at high concentrations $(50 \mu \mathrm{g} / \mathrm{mL})$, matrilin-3 functions as an adaptor protein to promote ECM anabolism. This signifies that the integration of matrilin-3 with matrix components is essential to maintain the cartilage ECM [62]. In vitro experiments by Pei et al. [48] showed that matrilin- 1 and -3 are essential to maintain chondrogenesis of synovial fibroblasts. Matrilin overexpression in synovial fibroblasts enhanced chondrogenesis after an initial 3 days of treatment with TGF- $\beta$, and maintained chondrogenesis even after the retrieval of TGF- $\beta$.

A functional knockout of matrilin-3 in a mouse model showed premature hypertrophy, chondrocyte clustering, osteophyte formation, fibrillation, and the degradation of the articular cartilage surface. Interestingly, mutations in matrilin-3 lead to MED and SEMD in humans, but the matrilin-3 knockout mouse model showed no skeletal deformity. However, these matrilin-3 null mice exhibit increased susceptibility to osteoarthritis during ageing. In matrilin-3 knockout mice, both the levels of collagen II and aggrecan were reduced compared to wild-type mice. These differences affect the structural integrity of the ECM [49]. In addition, matrilin-3 increases IL-Ra in chondrocytes, which in turn regulates the expression of collagen II, aggrecan, and ADAMTS5 [47]. Consequently, the matrilin-3 deletion in mice causes an imbalance in the maintenance of structural integrity with increased inflammation and degradation of ECM components. As a result, matrilin-3 null mice are predisposed to the initiation and progression of osteoarthritis. Hence, matrilin-3 plays an important role in maintaining the structural integrity of cartilage ECM. In addition, matrilin-3 null mice also show an increased bone mineral density [49]. However, it is not known whether the increased bone mineral density in matrilin-3 null mice is due to increased hypertrophy and ossification of the exposed subchondral plate. Matrilin-3 can regulate bone ECM components as evidenced by its expression in bone under normal conditions and its increased levels during osteoarthritis.

\section{Conclusions and Future Perspectives}

The ECM protein matrilin-3 plays a critical role in chondrogenesis, chondrocyte terminal differentiation, and chondrocyte function. However, it has also been implicated in the induction of osteoarthritis-associated gene expression in chondrocytes. At the molecular level, matrilin-3 interacts with TGF- $\beta$ and BMP-2 to maintain chondrocytes during development and for the homeostatic maintenance of the ECM of cartilage and bone. Mutation and gene knockout studies clearly indicate that matrilin-3 is an indispensable factor in skeletal development and homeostasis.

It is apparent that matrilin-3 affects and mediates the TGF- $\beta$ and BMP signaling pathways in chondrocytes. Therefore, further studies are required to understand: (1) matrilin-3 function during chondrogenesis in ECM assembly and ECM-cell communication in mesenchymal stem cells; (2) the involvement of matrilin-3 in vasculogenesis during osteoarthritis; and (3) the contribution of matrilin-3 to autoimmune diseases, such as rheumatoid arthritis.

Protein delivery systems, such as micro- or nanoparticles and biomimetic hydrogels, can be used for targeted applications. Micro- or nanoparticles can be usedasmatrilin-3 controlled release delivery systems, since low concentrations of soluble matrilin-3 induce ECM anabolism. Immobilized matrilin-3 also induces ECM anabolism; therefore, immobilizing matrilin-3 on biopolymers, such as hyaluronan, can be a novel approach. Further characterizing the precise functions of matrilin-3 would allow the development of new therapeutic strategies to facilitate the cartilage tissue repair and regeneration.

Acknowledgments: This research was supported by a grant from the National Research Foundation of Korea (NRF) funded by the Korean Government (MSIP) (No. 2015R1A5A1037656), the Korea Health Technology R\&D Project through the Korea Health Industry Development Institute (KHIDI), funded by the Ministry of Health and Welfare (HI14C3270, H16C0106), and the Basic Science Research Program through the National Research Foundation of Korea (NRF) funded by the Ministry of Education (NRF-2013R1A1A1076136) in Korea. 
Author Contributions: Manjunatha S. Muttigi collected the literature and designed and prepared the manuscript; Inbo Han and Hun-Kuk Park provided conceptual advice; Hansoo Park supervised and edited the manuscript; and Soo-Hong Lee supervised and edited the manuscript.

Conflicts of Interest: The authors declare that there are no conflicts of interest.

\section{Abbreviations}

The following abbreviations are used in this manuscript:

$\begin{array}{ll}\text { TGF- } \beta & \text { Transforming growth factor } \beta \\ \text { BMP } & \text { Bone morphogenetic protein } \\ \text { GDF5 } & \text { Growth differentiation factor 5 } \\ \text { FRZB } & \text { Secreted frizzled-related protein } 3 \\ \text { MATN3 } & \text { Matrilin-3 } \\ \text { ECM } & \text { Extracellular matrix } \\ \text { IL } & \text { Interleukin-1 } \\ \text { MMPs } & \text { Matrix metalloproteinases } \\ \text { ADAMTS } & \text { A disintegrin and metalloproteinase with thrombospondin motifs } \\ \text { VEGF } & \text { Vascular endothelial growth factor } \\ \text { RUNX2 } & \text { Runt-related transcription factor } \\ \text { VWFA } & \text { Von Willebrand factor A } \\ \text { EGF } & \text { Epidermal growth factor } \\ \text { MED } & \text { Multiple epiphyseal dysplasia } \\ \text { SEMD } & \text { Spondyloepimetaphyseal dysplasia }\end{array}$

\section{References}

1. Temenoff, J.S.; Mikos, A.G. Review: Tissue engineering for regeneration of articular cartilage. Biomaterials 2000, 21, 431-440. [CrossRef]

2. Sophia Fox, A.J.; Bedi, A.; Rodeo, S.A. The basic science of articular cartilage: Structure, composition, and function. Sports Health 2009, 1, 461-468. [CrossRef] [PubMed]

3. Hunter, D.J.; Felson, D.T. Osteoarthritis. BMJ 2006, 332, 639-642. [CrossRef] [PubMed]

4. Soltz, M.A.; Ateshian, G.A. Interstitial fluid pressurization during confined compression cyclical loading of articular cartilage. Ann. Biomed. Eng. 2000, 28, 150-159. [CrossRef] [PubMed]

5. Newman, A.P. Articular cartilage repair. Am. J. Sports Med. 1998, 26, 309-324. [PubMed]

6. Madry, H.; van Dijk, C.N.; Mueller-Gerbl, M. The basic science of the subchondral bone. Knee Surg. Sports Traumatol. Arthrosc. Off. J. ESSKA 2010, 18, 419-433. [CrossRef] [PubMed]

7. Reddi, A.H. Role of morphogenetic proteins in skeletal tissue engineering and regeneration. Nat. Biotechnol. 1998, 16, 247-252. [CrossRef] [PubMed]

8. Zhang, L.; Hu, J.; Athanasiou, K.A. The role of tissue engineering in articular cartilage repair and regeneration. Crit. Rev. Biomed. Eng. 2009, 37, 1-57. [CrossRef] [PubMed]

9. Felson, D.T. Clinical practice. Osteoarthritis of the knee. N. Engl. J. Med. 2006, 354, 841-848. [CrossRef] [PubMed]

10. Lane, N.E. Clinical practice. Osteoarthritis of the hip. N. Engl. J. Med. 2007, 357, 1413-1421. [CrossRef] [PubMed]

11. Ling, S.M.; Bathon, J.M. Osteoarthritis in older adults. J. Am. Geriatr. Soc. 1998, 46, 216-225. [CrossRef] [PubMed]

12. Felson, D.T.; Anderson, J.J.; Meenan, R.F. The comparative efficacy and toxicity of second-line drugs in rheumatoid arthritis. Results of two metaanalyses. Arthritis Rheum. 1990, 33, 1449-1461. [CrossRef] [PubMed]

13. Li, Y.; Xu, L.; Olsen, B.R. Lessons from genetic forms of osteoarthritis for the pathogenesis of the disease. Osteoarthr. Cartil. OARS Osteoarthr. Res. Soc. 2007, 15, 1101-1105. [CrossRef] [PubMed] 
14. Miyamoto, Y.; Mabuchi, A.; Shi, D.; Kubo, T.; Takatori, Y.; Saito, S.; Fujioka, M.; Sudo, A.; Uchida, A.; Yamamoto, S.; et al. A functional polymorphism in the 5'UTR of GDF5 is associated with susceptibility to osteoarthritis. Nat. Genet. 2007, 39, 529-533. [CrossRef] [PubMed]

15. Valdes, A.M.; Spector, T.D. The contribution of genes to osteoarthritis. Rheum. Dis. Clin. N. Am. 2008, 34, 581-603. [CrossRef] [PubMed]

16. Valdes, A.M.; Spector, T.D. The clinical relevance of genetic susceptibility to osteoarthritis. Best Pract. Res. Clin. Rheumatol. 2010, 24, 3-14. [CrossRef] [PubMed]

17. Southam, L.; Rodriguez-Lopez, J.; Wilkins, J.M.; Pombo-Suarez, M.; Snelling, S.; Gomez-Reino, J.J.; Chapman, K.; Gonzalez, A.; Loughlin, J. An SNP in the 5'-UTR of GDF5 is associated with osteoarthritis susceptibility in europeans and with in vivo differences in allelic expression in articular cartilage. Hum. Mol. Genet. 2007, 16, 2226-2232. [CrossRef] [PubMed]

18. Evangelou, E.; Chapman, K.; Meulenbelt, I.; Karassa, F.B.; Loughlin, J.; Carr, A.; Doherty, M.; Doherty, S.; Gomez-Reino, J.J.; Gonzalez, A.; et al. Large-scale analysis of association between GDF5 and FRZB variants and osteoarthritis of the hip, knee, and hand. Arthritis Rheum. 2009, 60, 1710-1721. [CrossRef] [PubMed]

19. Gu, J.; Rong, J.; Guan, F.; Jiang, L.; Tao, S.; Guan, G.; Tao, T. MATN3 gene polymorphism is associated with osteoarthritis in Chinese Han population: A community-based case-control study. Sci. World J. 2012, 2012. [CrossRef] [PubMed]

20. Pullig, O.; Tagariello, A.; Schweizer, A.; Swoboda, B.; Schaller, P.; Winterpacht, A. MATN3 (matrilin-3) sequence variation (pT303M) is a risk factor for osteoarthritis of the CMC1 joint of the hand, but not for knee osteoarthritis. Ann. Rheum. Dis. 2007, 66, 279-280. [CrossRef] [PubMed]

21. Krakow, D.; Rimoin, D.L. The skeletal dysplasias. Genet. Med. 2010, 12, 327-341. [CrossRef] [PubMed]

22. Mackie, E.J.; Ahmed, Y.A.; Tatarczuch, L.; Chen, K.S.; Mirams, M. Endochondral ossification: How cartilage is converted into bone in the developing skeleton. Int. J. Biochem. Cell Biol. 2008, 40, 46-62. [CrossRef] [PubMed]

23. Kwan Tat, S.; Lajeunesse, D.; Pelletier, J.P.; Martel-Pelletier, J. Targeting subchondral bone for treating osteoarthritis: What is the evidence? Best Pract. Res. Clin. Rheumatol. 2010, 24, 51-70. [CrossRef] [PubMed]

24. Karsdal, M.A.; Leeming, D.J.; Dam, E.B.; Henriksen, K.; Alexandersen, P.; Pastoureau, P.; Altman, R.D.; Christiansen, C. Should subchondral bone turnover be targeted when treating osteoarthritis? Osteoarthr. Cartil. OARS Osteoarthr. Res. Soc. 2008, 16, 638-646. [CrossRef] [PubMed]

25. Wan, R.; Hu, J.; Zhou, Q.; Wang, J.; Liu, P.; Wei, Y. Application of co-expressed genes to articular cartilage: New hope for the treatment of osteoarthritis (review). Mol. Med. Rep. 2012, 6, 16-18. [PubMed]

26. Ansboro, S.; Greiser, U.; Barry, F.; Murphy, M. Strategies for improved targeting of therapeutic cells: Implications for tissue repair. Eur. Cells Mater. 2012, 23, 310-318.

27. Lories, R.J.; Luyten, F.P. The bone-cartilage unit in osteoarthritis. Nat. Rev. Rheumatol. 2011, 7, 43-49. [CrossRef] [PubMed]

28. Burr, D.B.; Gallant, M.A. Bone remodelling in osteoarthritis. Nat. Rev. Rheumatol. 2012, 8, 665-673. [CrossRef] [PubMed]

29. Luyten, F.P.; Lories, R.J.; Verschueren, P.; de Vlam, K.; Westhovens, R. Contemporary concepts of inflammation, damage and repair in rheumatic diseases. Best Pract. Res. Clin. Rheumatol. 2006, 20, 829-848. [CrossRef] [PubMed]

30. Goldring, M.B.; Goldring, S.R. Articular cartilage and subchondral bone in the pathogenesis of osteoarthritis. Ann. N. Y. Acad. Sci. 2010, 1192, 230-237. [CrossRef] [PubMed]

31. Thambyah, A.; Broom, N. On new bone formation in the pre-osteoarthritic joint. Osteoarthr. Cartil. OARS Osteoarthr. Res. Soc. 2009, 17, 456-463. [CrossRef] [PubMed]

32. Berry, J.L.; Thaeler-Oberdoerster, D.A.; Greenwald, A.S. Subchondral pathways to the superior surface of the human talus. Foot Ankle 1986, 7, 2-9. [CrossRef] [PubMed]

33. Imhof, H.; Breitenseher, M.; Kainberger, F.; Rand, T.; Trattnig, S. Importance of subchondral bone to articular cartilage in health and disease. Top. Magn. Reson. Imaging TMRI 1999, 10, 180-192. [CrossRef] [PubMed]

34. Lyons, T.J.; McClure, S.F.; Stoddart, R.W.; McClure, J. The normal human chondro-osseous junctional region: Evidence for contact of uncalcified cartilage with subchondral bone and marrow spaces. BMC Musculoskelet. Disord. 2006, 7. [CrossRef]

35. Burr, D.B. The importance of subchondral bone in osteoarthrosis. Curr. Opin. Rheumatol. 1998, 10, $256-262$. [CrossRef] [PubMed] 
36. Bailey, A.J.; Mansell, J.P. Do subchondral bone changes exacerbate or precede articular cartilage destruction in osteoarthritis of the elderly? Gerontology 1997, 43, 296-304. [CrossRef] [PubMed]

37. Wagener, R.; Ehlen, H.W.; Ko, Y.P.; Kobbe, B.; Mann, H.H.; Sengle, G.; Paulsson, M. The matrilins-Adaptor proteins in the extracellular matrix. FEBS Lett. 2005, 579, 3323-3329. [CrossRef] [PubMed]

38. Klatt, A.R.; Becker, A.K.; Neacsu, C.D.; Paulsson, M.; Wagener, R. The matrilins: Modulators of extracellular matrix assembly. Int. J. Biochem. Cell Biol. 2011, 43, 320-330. [CrossRef] [PubMed]

39. Wagener, R.; Kobbe, B.; Paulsson, M. Primary structure of matrilin-3, a new member of a family of extracellular matrix proteins related to cartilage matrix protein (matrilin-1) and Von Willebrand factor. FEBS Lett. 1997, 413, 129-134. [CrossRef]

40. Deak, F.; Wagener, R.; Kiss, I.; Paulsson, M. The matrilins: A novel family of oligomeric extracellular matrix proteins. Matrix Biol. J. Int. Soc. Matrix Biol. 1999, 18, 55-64. [CrossRef]

41. Klatt, A.R.; Nitsche, D.P.; Kobbe, B.; Morgelin, M.; Paulsson, M.; Wagener, R. Molecular structure and tissue distribution of matrilin-3, a filament-forming extracellular matrix protein expressed during skeletal development. J. Biol. Chem. 2000, 275, 3999-4006. [CrossRef] [PubMed]

42. Zhang, Y.; Chen, Q. Changes of matrilin forms during endochondral ossification. Molecular basis of oligomeric assembly. J. Biol. Chem. 2000, 275, 32628-32634. [CrossRef] [PubMed]

43. Fresquet, M.; Jowitt, T.A.; Ylostalo, J.; Coffey, P.; Meadows, R.S.; Ala-Kokko, L.; Thornton, D.J.; Briggs, M.D. Structural and functional characterization of recombinant matrilin-3 A-domain and implications for human genetic bone diseases. J. Biol. Chem. 2007, 282, 34634-34643. [CrossRef] [PubMed]

44. Mostert, A.K.; Dijkstra, P.F.; Jansen, B.R.; van Horn, J.R.; de Graaf, B.; Heutink, P.; Lindhout, D. Familial multiple epiphyseal dysplasia due to a matrilin-3 mutation: Further delineation of the phenotype including 40 years follow-up. Am. J. Med. Genet. Part A 2003, 120A, 490-497. [CrossRef] [PubMed]

45. Borochowitz, Z.U.; Scheffer, D.; Adir, V.; Dagoneau, N.; Munnich, A.; Cormier-Daire, V. Spondylo-epi-metaphyseal dysplasia (SEMD) matrilin 3 type: Homozygote matrilin 3 mutation in a novel form of semd. J. Med. Genet. 2004, 41, 366-372. [CrossRef] [PubMed]

46. Mabuchi, A.; Haga, N.; Maeda, K.; Nakashima, E.; Manabe, N.; Hiraoka, H.; Kitoh, H.; Kosaki, R.; Nishimura, G.; Ohashi, H.; et al. Novel and recurrent mutations clustered in the Von Willebrand factor a domain of MATN3 in multiple epiphyseal dysplasia. Hum. Mutat. 2004, 24, 439-440. [CrossRef] [PubMed]

47. Jayasuriya, C.T.; Goldring, M.B.; Terek, R.; Chen, Q. Matrilin-3 induction of Il-1 receptor antagonist is required for up-regulating collagen II and aggrecan and down-regulating ADAMTs-5 gene expression. Arthritis Res. Ther. 2012, 14. [CrossRef] [PubMed]

48. Pei, M.; Luo, J.; Chen, Q. Enhancing and maintaining chondrogenesis of synovial fibroblasts by cartilage extracellular matrix protein matrilins. Osteoarthr. Cartil. OARS Osteoarthr. Res. Soc. 2008, 16, 1110-1117. [CrossRef] [PubMed]

49. Van der Weyden, L.; Wei, L.; Luo, J.; Yang, X.; Birk, D.E.; Adams, D.J.; Bradley, A.; Chen, Q. Functional knockout of the matrilin-3 gene causes premature chondrocyte maturation to hypertrophy and increases bone mineral density and osteoarthritis. Am. J. Pathol. 2006, 169, 515-527. [CrossRef] [PubMed]

50. Chapman, K.L.; Mortier, G.R.; Chapman, K.; Loughlin, J.; Grant, M.E.; Briggs, M.D. Mutations in the region encoding the Von Willebrand factor a domain of matrilin-3 are associated with multiple epiphyseal dysplasia. Nat. Genet. 2001, 28, 393-396. [CrossRef] [PubMed]

51. Otten, C.; Wagener, R.; Paulsson, M.; Zaucke, F. Matrilin-3 mutations that cause chondrodysplasias interfere with protein trafficking while a mutation associated with hand osteoarthritis does not. J. Med. Genet. 2005, 42, 774-779. [CrossRef] [PubMed]

52. Wang, Y.C.; Liu, J.S.; Chen, J.Y.; Wu, S.Q.; Wang, G.R.; Nie, J.; Zhang, S.K.; Guo, Q.L.; Luo, J.M. Multiple functions of the first EGF domain in matrilin-3: Secretion and endoplasmic reticulum stress. Int. J. Mol. Med. 2015, 36, 1648-1656. [CrossRef] [PubMed]

53. Cotterill, S.L.; Jackson, G.C.; Leighton, M.P.; Wagener, R.; Makitie, O.; Cole, W.G.; Briggs, M.D. Multiple epiphyseal dysplasia mutations in MATN3 cause misfolding of the A-domain and prevent secretion of mutant matrilin-3. Hum. Mutat. 2005, 26, 557-565. [CrossRef] [PubMed]

54. Jayasuriya, C.T.; Zhou, F.H.; Pei, M.; Wang, Z.; Lemme, N.J.; Haines, P.; Chen, Q. Matrilin-3 chondrodysplasia mutations cause attenuated chondrogenesis, premature hypertrophy and aberrant response to TGF- $\beta$ in chondroprogenitor cells. Int. J. Mol. Sci. 2014, 15, 14555-14573. [CrossRef] [PubMed] 
55. Volk, S.W.; Luvalle, P.; Leask, T.; Leboy, P.S. A BMP responsive transcriptional region in the chicken type X collagen gene. J. Bone Miner. Res. 1998, 13, 1521-1529. [CrossRef] [PubMed]

56. Yang, X.; Trehan, S.K.; Guan, Y.; Sun, C.; Moore, D.C.; Jayasuriya, C.T.; Chen, Q. Matrilin-3 inhibits chondrocyte hypertrophy as a bone morphogenetic protein-2 antagonist. J. Biol. Chem. 2014, 289, 34768-34779. [CrossRef] [PubMed]

57. Stefansson, S.E.; Jonsson, H.; Ingvarsson, T.; Manolescu, I.; Jonsson, H.H.; Olafsdottir, G.; Palsdottir, E.; Stefansdottir, G.; Sveinbjornsdottir, G.; Frigge, M.L.; et al. Genomewide scan for hand osteoarthritis: A novel mutation in matrilin-3. Am. J. Hum. Genet. 2003, 72, 1448-1459. [CrossRef] [PubMed]

58. Pullig, O.; Weseloh, G.; Klatt, A.R.; Wagener, R.; Swoboda, B. Matrilin-3 in human articular cartilage: Increased expression in osteoarthritis. Osteoarthr. Cartil. OARS Osteoarthr. Res. Soc. 2002, 10, 253-263. [CrossRef] [PubMed]

59. Mann, H.H.; Sengle, G.; Gebauer, J.M.; Eble, J.A.; Paulsson, M.; Wagener, R. Matrilins mediate weak cell attachment without promoting focal adhesion formation. Matrix Biol. J. Int. Soc. Matrix Biol. 2007, 26, 167-174. [CrossRef] [PubMed]

60. Klatt, A.R.; Klinger, G.; Paul-Klausch, B.; Kuhn, G.; Renno, J.H.; Wagener, R.; Paulsson, M.; Schmidt, J.; Malchau, G.; Wielckens, K. Matrilin-3 activates the expression of osteoarthritis-associated genes in primary human chondrocytes. FEBS Lett. 2009, 583, 3611-3617. [CrossRef] [PubMed]

61. Klatt, A.R.; Paul-Klausch, B.; Klinger, G.; Hillebrand, U.; Kuhn, G.; Kobbe, B.; Renno, J.H.; Johannis, W.; Paulsson, M.; Wagener, R. The matrilin-3 VWA1 domain modulates interleukin-6 release from primary human chondrocytes. Osteoarthr. Cartil. OARS Osteoarthr. Res. Soc. 2013, 21, 869-873. [CrossRef] [PubMed]

62. Vincourt, J.B.; Etienne, S.; Grossin, L.; Cottet, J.; Bantsimba-Malanda, C.; Netter, P.; Mainard, D.; Libante, V.; Gillet, P.; Magdalou, J. Matrilin-3 switches from anti- to pro-anabolic upon integration to the extracellular matrix. Matrix Biol. J. Int. Soc. Matrix Biol. 2012, 31, 290-298. [CrossRef] [PubMed]

(C) 2016 by the authors; licensee MDPI, Basel, Switzerland. This article is an open access article distributed under the terms and conditions of the Creative Commons Attribution (CC-BY) license (http://creativecommons.org/licenses/by/4.0/). 